\title{
Leiomiosarcoma intraóseo mandibular
}

\author{
Mandibular intraosseous leiomyosarcoma
}

\author{
A. López Ceres' ${ }^{1}$, F. Ruiz Delgado', L. Bermudo Añino²
}

Resumen: Los leiomiosarcomas son neoplasias malignas mesenquimales derivadas del músculo liso. Los leiomiosarcomas intraóseos mandibulares primarios son muy raros. Se cree que proceden de la musculatura lisa de la pared de los vasos sanguíneos. Pueden presentarse a cualquier edad, sin ninguna predilección y afectan preferentemente a hombres, con una relación hombre-mujer de 2:1. La excisión quirúrgica completa está asociada con una menor recidiva y mayor supervivencia. La radioterapia es efectiva en el tratamiento de la enfermedad microscópica residual. Presentamos el caso de un leiomiosarcoma intraóseo mandibular.

Palabras clave: Leiomiosarcoma mandibular; Tumor de células fusiformes.

Recibido: 09.06 .05

Aceptado: 18.12 .06

\begin{abstract}
Leiomyosarcomas are malignant mesenchymal neoplasms of smooth muscle differentiation. Leiomyosarcomas occurring in the jawbones are exceedingly rare, and are believed to arise from the musculature of the tunica of blood vessels. Intraoral cases may present at any age with no predilection for any age group. They occur predominantly in males, with a male to female ratio of approximately 2:1. Complete surgical excision is associated with low recurrence and longer survival. Radiotherapy is effective in the treatment of microscopic disease.
\end{abstract}

Key words: Mandibular leiomyosarcomas; Spindle-cell tumour.

1. Médico Residente.

2. Jefe de Sección.

Servicio de Cirugía Oral y Maxilofacial.

Complejo Hospitalario Carlos Haya. Málaga, España

\section{Correspondencia:}

Ana López Ceres

c/ Luis Taboada No38, Blq 1, $1^{\circ} \mathrm{B}$

29017 Málaga, España

Email: analopezceres@gmail.com 


\section{Introducción}

Los leiomiosarcomas son neoplasias malignas mesenquimales derivadas del músculo liso que suponen un 5-10\% de todos los sarcomas de tejidos blandos. Se suelen dividir en tres grupos anatómicos: tejidos blandos, cutáneos y vasculares. Las zonas donde se desarrollan con mayor frecuencia son el tracto gastrointestinal, el tracto urinario y el aparato genital femenino. Los leiomiosarcomas intraóseos primarios son muy raros, con una predilección por los huesos largos, más raro aún, su aparición en huesos maxilomandibulares, debido a la poca presencia de tejido muscular liso en dicha zona. ${ }^{1}$

Aunque infrecuente, la posibilidad de que un leiomiosarcoma primario de otra localización metastatize a nivel intraoral existe, y siempre debe ser descartada ante un diagnóstico de leiomiosarcoma. $^{2}$

Las características histopatológicas del tumor no son consideradas factores pronóstico en los leiomiosarcomas. El pronóstico del leiomiosarcoma de tejidos blandos depende, tanto del tratamiento quirúrgico, como de la localización anatómica, ya que los leiomiosarcomas de localización periférica se comportan mucho más agresivamente que los localizados en los tejidos profundos. ${ }^{3} \mathrm{~A}$ pesar de su localización, los leiomiosarcomas intraorales son tumores muy agresivos asociados a una alta recidiva local y/o metástasis a distancia con un índice de supervivencia muy bajo.4,5

Presentamos el caso de un leiomiosarcoma intraóseo mandibular.

\section{Caso clínico}

Presentamos el caso de una paciente de 63 años de edad, remitida a nuestra consulta por su odontólogo, quejándose de una masa dolorosa en la región del canino inferior derecho, que había descubierto cuatro semanas antes. Negaba historia de alteración neurosensorial, disfagia, odinofagia, pérdida de peso o fiebre. El examen físico demostraba una mínima tumefacción facial y asimetría. Intraoralmente, se observaba un abombamiento de la tabla lingual derecha mandibular a nivel del canino, con vestibulización del mismo. No se palpaban adenopatías cervicales. La ortopantomografía demostró un area radiolúcida, de bordes regulares, en relación con el canino, de $2 \mathrm{~cm}$ de diámetro máximo. Se diagnosticó como patología quística benigna (Fig. 1).

Se realizó una biopsia incisional bajo anestesia local. Los estudios microscópicos concluyeron que era una neoplasia maligna de células fusiformes.

Como estudio de extensión se realizó una TC de tórax, de abdomen y de pelvis, que fue absolutamente negativo.

La paciente fue intervenida bajo anestesia general tres semanas después de su primera visita. En ese momento, presentaba una masa que había emergido por la cara vestibular, en la zona de la biopsia. Se realizó una disección cervical supraomohioidea derecha, con exéresis de la glándula submaxilar y los ganglios linfáticos regionales. La mandíbula fue resecada desde la sínfisis hasta el primer molar inferior derecho. La pieza quirúrgica y el vaciamiento cervical esta-

\section{Introduction}

Leiomyosarcomas are malignant mesenchymal neoplasms with a smooth muscle origin that represent 5-10\% of all soft tissue sarcomas. They tend to be divided into three anatomic groups: soft, cutaneous and vascular tissue. The areas where they develop with greater frequency are the gastrointestinal tract, urinary tract and the female genital apparatus. Primary intraosseous leiomyosarcomas are very rare, as they have a predilection for long bones. Their appearance in the jaw bones is even rarer due to there being very little smooth muscle in this area. ${ }^{1}$

Although somewhat uncommon, there is a possibility of a primary leiomyosarcoma in another location metastasizing to an intraoral location, and this should always be ruled out when there is a diagnosis of leiomyosarcoma. ${ }^{2}$

The histopathologic characteristics of the tumor are not considered prognostic factors in leiomyosarcomas. The prognosis of leiomyosarcomas of soft tissue depends on the surgical treatment as well as the anatomic location, as leiomyosarcomas with a peripheral location behave much more aggressively that those located in the deeper tissues. ${ }^{3}$ In spite of their location, intraoral leiomyosarcomas are very aggressive tumors with high local recurrence and/or distant metastasis, and the survival rate is very low.., 5

We present a case of mandibular intraosseous leiomyosarcoma.

\section{Case report}

We present the case of a female patient, 63 years of age, who was referred to our department by her dentist, complaining of a painful mass in the region of the lower right canine, which she had discovered four weeks previously. She denied having experienced neurosensory disturbance, dysphagia, odynphagia, weight loss or fever. The physical examination showed minimal facial swelling and asymmetry. Intraoral vestibular bulging could be observed on the right mandibular lingual surface by the canine. No neck adenopathy was noted. The orthopantomography showed a radiolucid area, with regular borders by the canine, with a $2 \mathrm{~cm}$ diameter maximum. It was diagnosed as having a benign cystic pathology.

An incisional biopsy was carried out under local anesthesia. The microscopic studies concluded that it was a malignant neoplasm with spindle cells. Extension studies were carried out with a CAT scan of thorax, abdomen and pelvis that were completely negative.

The patient was operated under general anesthesia three weeks after her first visit. At this point the mass had emerged on the vestibular side in the area of the biopsy Right-sided, supraomohyoid neck dissection was carried out and the submaxillary gland was excised together with the regional lymph nodes. The mandible was resected from the symphysis to the 
ban, macroscópicamente, libres de tumor (Fig. 2). Para la reconstrucción primaria del defecto se utilizó una placa de reconstrucción.

En el postoperatorio inmediato, la paciente desarrolló una infección cervical, con una comunicación orocervical, a pesar de la sonda nasogástrica colocada en el momento de la cirugía. A pesar del tratamiento antibiótico intravenoso, la paciente no mejoró, con lo que se retiró la placa de reconstrucción bajo anestesia general. Posteriormente, la paciente evolucionó favorablemente, y fue dada de alta en el 20 día postoperatorio.

El estudio inmunohistoquímico de la biopsia y de la pieza quirúrgica mostraban que las células tumorales eran reactivas para vimentina y actina músculoespecífica. Asimismo, también eran reactivas para desmina. Finalmente, se diagnosticó de leiomiosarcoma grado II.

La paciente presenta seguimientos periódicos en nuestra consulta, hace ya 15 meses del diagnóstico, y está libre de recidivas o metástasis.

\section{Discusión}

Carmody y cols. ${ }^{6}$ en 1944 fue el primer investigador en describir un leiomiosarcoma mandibular. Se cree que los leiomiosarcomas mandibulares proceden de la musculatura lisa de la pared de los vasos sanguíneos. Los huesos maxilares son el sitio de predilección de los leiomiosarcomas intraorales, aproximadamente el $50 \%$ de estos tumores afectan al maxilar o a la mandíbula.1,4

Las posibles zonas de origen de los leiomiosarcomas intraorales son: 1) Las papilas circunvaladas de la lengua, 2) células mesenquimales pluripotenciales indiferenciadas, 3 ) elementos del tejido muscular liso de las paredes de los vasos sanguíneos, 4) sistema neurovascular, 5) el músculo erector del pelo en los folículos pilosos aberrantes de la mejilla y 6) células mioepiteliales de las glándulas mucosas. 7,8

El síntoma más común de presentación en los estadios precoces del leiomiosarcoma mandibular es el desarrollo de una masa de crecimiento lento, no ulcerada, que puede o no ser dolorosa. No se ha demostrado ningún factor predisponente o etiológico en estos tumores. ${ }^{9}$

Pueden presentarse a cualquier edad, sin ninguna predilección, y afecta preferentemente a hombres, con una relación hombremujer de 2:1.10

Las metástasis a distancia del leiomiosarcoma intraoral aparecen en un $39 \%$ de los casos. ${ }^{8}$ Los pulmones son la zona de mayor diagnosis she is free of recurrence or metastases.

\section{Discussion}

In 1944 Carmody et al. ${ }^{6}$ was the first researcher to describe mandibular leiomyosarcoma. It is thought that mandibular leiomyosarcomas arise in the smooth muscles of blood vessel walls. The maxillary bones are the location of choice of intraoral leiomyosarcomas, approximately $50 \%$ of these tumors affect the maxilla or mandible. ${ }^{1,4}$

The possible areas where intraoral leiomyosarcoma may arise are: 1) the rounded papillae of the tongue, 2) undifferentiated pluripotential mesenchymal cells, 3) smooth muscle tissue of the blood vessel walls, 4) neurovascular system, 5) erector muscle of aberrant hair follicles of the cheek, and 6) myoepithelial cells of the mucosal glands. 7,8

The most common symptom at onset during the early stages of mandibular leiomyosarcoma is the development of 
afectación, a diferencia de los tumores que se originan en otras partes del organismo, que metastatizan generalmente en el pulmón y en el hígado. La afectación ganglionar cervical ocurre en un $15 \%$ de los casos. También han sido descritos leiomiosarcomas metastáticos en la cavidad oral. ${ }^{2}$

Radiológicamente, estas lesiones no tienen ninguna característica que los diferencie del resto de lesiones, y puede simular cualquier tumoración expansiva, o destructiva de la mandíbula. Se han descrito lesiones líticas con márgenes mal definidos, elevación periostal, calcificaciones y destrucción cortical. ${ }^{11}$

El diagnóstico microscópico de las

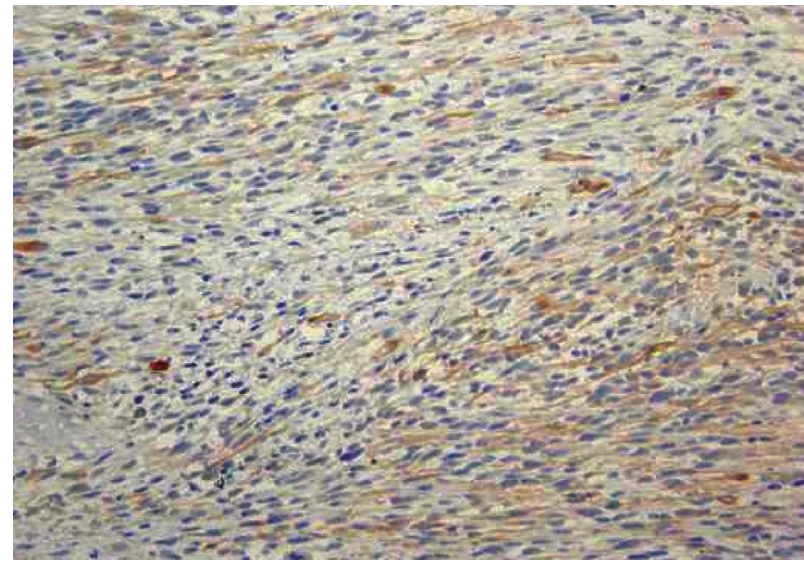

Figura 3. Corte histopatológico, reactivo a actina específica para músculo.

Figure 3. Histopathologic slice showing reaction to muscle-specific actin. a slow-growing, non-ulcerated mass that may or may not be tender. No predisposing or etiologic factor for these tumors has been demonstrated. ${ }^{9}$

They can arise at any age, as they have no specific age predilection, and they particularly affect males with male-female ratio of 2:1.10 Distant metastases of intraoral leiomyosarcoma appear in up to $39 \%$ of cases. ${ }^{8}$ The lungs are affected the most, unlike tumors that arise in other parts of the organism, which metastasize generalesiones de la musculatura lisa de la mandíbula son difíciles, debido al pequeño tamaño de las piezas de biopsia y la diversidad de lesiones. El diagnóstico diferencial de las lesiones de células fusiformes debe incluir lesiones benignas y malignas, como puede ser el fibroma no osificante, el histiocitoma fibroso maligno, el sarcoma neurogénico y el fibrosarcoma. La diferenciación miogénica, supuesta característica del leiomiosarcoma, puede aparecer también en otros sarcomas. Tomar una buena muestra de la pieza quirúrgica, así como el estudio inmunocitoquímico, y particularmente, la actina, puede ayudar a diferenciarlo de otras lesiones. ${ }^{12}$

El éxito del tratamiento inicial es un factor pronóstico importante, ya que la excisión quirúrgica completa está asociada con una menor recidiva y mayor supervivencia. En presencia de afectación adenopática, se deberá llevar a cabo una disección radical modificada de cuello. ${ }^{3,13}$

La radioterapia postoperatoria en los leiomiosarcomas demuestra algún beneficio mejorando la supervivencia y el tiempo libre de recidiva. En el tratamiento de los sarcomas de tejidos blandos, la radioterapia de forma aislada es capaz de conseguir un control local a muy altas dosis. El control local de la radioterapia aislada es menor que si se da asociada a la cirugía. ${ }^{10}$ La radioterapia es efectiva en el tratamiento de la enfermedad microscópica residual, por tanto, mejor utilizarla de forma adyuvante postoperatoriamente.

La quimioterapia se tiende a utilizar de forma paliativa y puede mejorar la supervivencia y calidad de vida en los pacientes con enfermedad metastásica o tumores inoperables, pero no se utiliza como primera maniobra terapéutica de rutina. ${ }^{14}$

\section{Conclusiones}

El leiomiosarcoma intraoral es un tumor muy agresivo, y para conseguir un buen resultado, lo mejor es tratarlo quirúrgicamente, de forma precoz y agresiva, siendo su diagnóstico por biopsia, debiendo incluir diagnóstico de extensión para descartar tumor primario en otra localización. ly in the lungs and liver. Neck node involvement occurs 15\% of the time. Metastatic leiomyosarcoma has been described in the oral cavity. ${ }^{2}$

Radiologically these lesions do not have any characteristics that differentiate them from other lesions, and they can simulate any expansive or destructive lesion of the mandible. Lytic lesions have been described with ill-defined margins, periosteal elevation, calcification and cortical destruction. ${ }^{11}$

Microscopic diagnosis of the smooth muscle lesions of the mandible is difficult, due to the small biopsy sizes and the diversity of the lesions. The differential diagnosis of spindle shaped lesions should include benign and malignant lesions, such as non-ossifying fibroma, malignant fibrous histiocytoma, neurogenic sarcoma and fibrosarcoma. Myogenic differentiation, presumably a characteristic of leiomyosarcoma, can also appear in other sarcomas. Taking a good sample of the surgical specimen, as well as the immunocytochemical study, and particularly actin can help in differentiating this from other lesions. ${ }^{12}$

The success of the initial treatment is an important prognostic factor, as complete surgical excision is associated with lower recurrence and greater survival. When there is nodal involvement, modified radical dissection of the neck should be carried out. 3,13

Postoperative radiotherapy of leiomyosarcomas appears to be beneficial as survival improves together with the recurrence-free period. When treating soft tissue sarcomas, radiotherapy on its own is capable of achieving local control with high doses. Local control with just radiotherapy is lower than if associated with surgery. ${ }^{10}$ Radiotherapy is effective for treating residual microscopic disease; therefore, it is better if used as adjuvant treatment postoperatively.

Chemotherapy tends to be palliative and survival can improve together with the quality of life of those patients with metastatic disease or inoperable tumors, but it is not used routinely as an initial therapeutic maneuver. ${ }^{14}$ 


\section{Bibliografía}

1. Dry SM, Jorgesen JL, Fletcher CM. Leiomyosarcomas of the oral cavity: an unusual topographic subset easily mistaken for nonmesenchymal tumours. Histopathol 2000;36:210-20.

2. Allen CM, Neville B, Damm DD, Marsh W. Leiomyosarcoma metastatic to the oral region. Report of three cases. Oral Surg Oral Med Oral Pathol 1993;76:7526.

3. Nikitakis NG, Lopes MA, Bailey JS, Blanchaert RH, Ord RA, Sauk JJ. Oral leiomyosarcoma: review of the literature and report of two cases with assessment of the prognostic and diagnostic significance of immunohistochemical and molecular markers. Oral Oncol 2002;38:201-8.

4. Izumi K, Maeda T, Cheng J, Saku T. Primary leiomyosarcoma of the maxilla with regional lymph node metastasis. Report of a case and review of the literature. Oral Surg Oral Med Oral Pathol Oral Radiol Endod 1995;80:310-9.

5. Lo Muzio L, Favia G, Mignonga MD, Piattelli A, Mariorano E. Primary intraoral leiomyosarcoma of the tongue: an immunohistochemical study and review of the literatura. Oral Oncol 2000;36:519-24.

6. Carmody TE, Janney HM, Husesman HAL. Leiomyosarcoma of the mandible. Report of a case. J Am Dent Assoc 1944;31:1110-3.

7. Carter LC, Aguirre A, Boyd B, DeLacure M. Primary leiomyosarcoma of the mandible in a 7-year-old girl: Report of a case and review of the literature. Oral Surg Oral Med Oral Pathol Oral Radiol Endod 1999;87:477-84.

8. Goldschmidt PR, Goldschmidt JD, Eisenberg E. Leiomyosarcoma presenting as a mandibular gingival swelling: A case report. J Periodontol 1999;70:84-9.

9. Laccourreye O, Cauchois R, Laccourreye L, Maurice D, Carnot F, Brasnu D. Primary leiomyosarcoma of the mandible. Am J Otolaryngol 1996;17:415-9.

10. Schenberg ME, Wlootweg PJ, Koole R. Leiomyosarcomas of the oral cavity. Report of four cases and review of the literature. / Craniomaxillofac Surg 1993;21:3427.

11. Hilpert PL, Radecki PD, Edmonds P. Primary leiomyosarcoma (LMS) of the mandible. Skeletal Radiol 1986;15:570-4.

12. Miettinen M, Lehto VP, Ekblom P, Tasanem A, Virtanen I. Leiomyosarcoma of the mandible: diagnosis as aided immunohistochemical demonstration of desmin and laminin. J Oral Pathol 1984;13:373-81.

13. Martis C. Leiomyosarcoma of the maxilla: report of two cases. J Oral Surg 1978;36:62-5.

14. Wile AF, Evans HL, Romsdahl MM. Leiomyosarcoma of soft tissue: a clinicopathologic study. Cancer 1981;48:1022-32.

\section{Conclusions}

Intraoral leiomyosarcoma is a very aggressive tumor and, in order to achieve good results, it is better for it to be treated surgically, both promptly and aggressively. Its diagnosis is through biopsy, and an extension study should be included in order to rule out a primary tumor in another location. 